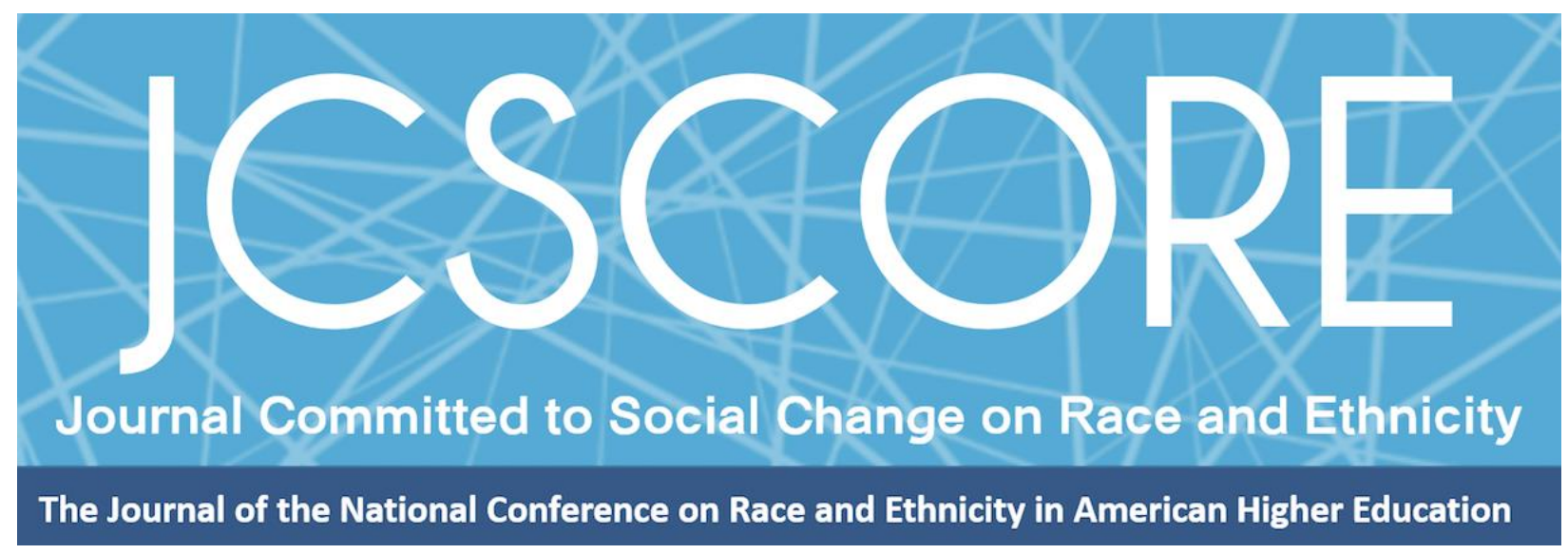

\title{
THE NEW JIM CROW IN HIGHER EDUCATION: A CRITICAL RACE ANALYSIS OF POSTSECONDARY POLICY RELATED TO DRUG FELONIES
}

\author{
Kenyon Lee Whitman \\ University of California, Riverside \\ Stephen A. Exarhos \\ University of Minnesota
}

Journal Committed to Social Change on Race and Ethnicity

Volume 6, Issue 2 | 2020

\section{Copyright and Open Access}

(C) 2020 Kenyon Lee Whitman \& Stephen A. Exarhos

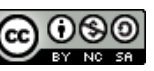

This work is licensed under a Creative Commons Attribution-NonCommercial-ShareAlike 4.0 International License. Permission of the authors is required for distribution and for all derivative works, including compilations and translations. Quoting small sections of text is allowed as long as there is appropriate attribution and the article is used for non-commercial purposes.

The Journal Committed to Social Change on Race and Ethnicity (ISSN 2642-2387) is published by the National Conference on Race and Ethnicity (NCORE), a production of the University of Oklahoma, in partnership with the University of Oklahoma Libraries. 
Journal Committed to Social Change on Race and Ethnicity | Volume 6, Issue 2 | 2020

\title{
The New Jim Crow in Higher Education: A Critical Race Analysis of Postsecondary Policy Related to Drug Felonies
}

\author{
Kenyon Lee Whitman \\ University of California, Riverside \\ Stephen A. Exarhos \\ University of Minnesota
}

\begin{abstract}
In this paper, critical race theory and critical race praxis for educational research are used to frame an analysis of the 1998 Amendments to the Higher Education Act of 1965 (HEA98) that limits access to financial aid for students who have been convicted of a drug felony. The authors explain how the HEA98 disenfranchises Black and Latinx college student populations. This policy is a form of institutional racism against the disproportionately large number of Black and Latinx individuals that have been convicted of drug-related crimes, which creates a caste system of college access and support. This policy analysis highlights data on incarcerated populations that link the policing of drug offenses to racial profiling and discrimination (e.g., "the War on Drugs" and the 1994 Crime Bill), questions the motivations for reducing access to education in drug offenders, reviews causes and inhibitors of recidivism in drug offenders to make the case for the promotion of education in recently-released offenders, and highlights empirical data that supports expanding access to these people. The authors conclude the paper with recommendations to progress toward racial educational equity. This paper is directed toward higher education scholars, practitioners, and policy makers who possess a strategic critical orientation towards racial equity in education.
\end{abstract}

Once you're labeled a felon, the old forms of discrimination-employment discrimination, housing discrimination, denial of the right to vote, denial of educational opportunity, denial of food stamps and other public benefits, and exclusion from jury service-are suddenly legal ... We have not ended racial caste in America; we have merely redesigned it. (Alexander, 2010, p. 2)

In her landmark book, The New Jim Crow: Mass Incarceration in the Age of

Colorblindness, Michelle Alexander (2010) describes how people who commit felonies in America are rendered second-class citizens due to the way society treats these people after they are released from prison. Tragically and unjustly, mass incarceration 
Journal Committed to Social Change on Race and Ethnicity | Volume 6, Issue 2 | 2020

primarily impacts Black and Latinx ${ }^{1}$ people as they are disproportionally represented in the criminal justice system (Wagner \& Sawyer, 2018). Consequently, Black and Latinx people are shut out from voting, owning a firearm, qualifying for subsidized housing, food stamps, and other federal programs.

This paper addresses how People of Color who have been convicted of drug crimes are treated in postsecondary education. Those who are convicted of a drug felony can also find themselves shut out of postsecondary education due to federal and state policies blocking access to financial aid as a result of the 1998 amendments of the Higher Education Act of 1965 (HEA98). This paper asserts that the HEA98 is a racialized policy aimed to shut People of Color out of the college-going process as it coincided with the emergence of the War on Drugs and the 1994 Crime Bill that sparked mass incarceration.

Compared to a high school diploma, possessing a college degree substantially increases an individual's career earning potential over a lifetime (Burnsed, 2011). This is important in reducing poverty status, which can lead to crime motivated by desperation and survival (MacKenzie, 2006). Moreover, postsecondary education dramatically reduces the rate at which previously convicted individuals commit crimes after serving their punishment known as recidivism (MacKenzie, 2006; Mukamal \& Silbert, 2018). Mukamal and Silbert (2018) affirm that higher education in any form can indeed reduce criminality and recidivism.

\footnotetext{
${ }^{1}$ Because we refer to general populations in this article and not to specific individuals, we use the term Latinx to be inclusive of all individuals of Latin American descent (Salinas \& Lozano, 2019). We invoke the term when referring to populations described as Latino in cited sources.
} 
Journal Committed to Social Change on Race and Ethnicity | Volume 6, Issue 2 | 2020

We understand there are numerous non-economic benefits of pursuing a higher educational degree (Chan, 2016), with that said we underscore the economic gains of obtaining a four-year bachelor's degree; research by Georgetown University states that college graduates earn $\$ 1$ million more than high school graduates over their lifetime, moreover, the research showed that students earning potential was even greater in the higher-paying college majors (e.g. engineering); it was a difference of $\$ 3$ million (Carnevale et al., 2015). When specifically looking at individuals who have been formerly incarcerated, research shows that a higher education greatly decreases their chances of re-entering prison, and increases their lifetime earning potential and career opportunities (Olson et al., 2015). However, being denied financial aid makes it difficult to persist and reap these benefits (Gross et al., 2015; Gross et al., 2012). Tax-payers should also be concerned as the average cost of tuition was $\$ 10,440$ at a public university in the United States in 2019-2020 (College Board, 2019) and on average it costs $\$ 31,286$ to incarcerate someone in the United States (Henrichson \& Delaney, 2012).

To note, there are programs (e.g., Project Rebound and Underground Scholars) that advocate for education for current and formerly incarcerated populations (MacKenzie, 2006; Mukamal \& Silbert, 2018). However, many of these individuals never enroll in any form of higher education after their release (Weissman et al., 2010). There are different causes for these obstructions. One comes in the college application process. Some colleges and universities ask applicants to disclose prior criminal activity as a qualifier in their college applications (Weissman et al., 2010). Another cause is the federal financial aid application process, through which students who have been 
Journal Committed to Social Change on Race and Ethnicity | Volume 6, Issue 2 | 2020

convicted of a drug felony are shut out of federal student aid via institutional and federal policy.

We understand that formerly incarcerated people face many issues in gaining access to higher education. However, the empirical data suggests that banning students from accessing federal student aid because of a drug felony is discriminatory against an already marginalized group, People of Color (Weissman et al., 2010). We argue that restricting access to financial aid establishes barriers impeding enrollment in a four-year institution and reduces the likelihood of persistence through graduation (Gross et al., 2015; Gross et al., 2012).

This paper is particularly timely due to the recent increasing trend of state-wide legalization of marijuana in the United States. A substantial population of current and past drug offenders have convictions that are no longer violations of the law, and they deserve commutation. This paper serves as a call to reconsider discriminatory federal student aid structures to help reintegrate into society those convicted of drug offenses.

The purpose of this policy analysis is to understand how HEA98 disenfranchises Black and Latinx college student populations. We assert that this policy is a form of institutional racism against the disproportionately large number of Black and Latinx individuals that make up the national prison population (Bureau of Justice Statistics, 2014; Drug Policy Alliance, 2016). No empirical evidence suggests withholding access from drug offenders to college programs makes college campuses safer or reduces recidivism (Weissman et al., 2010), yet the HEA98 limits access to financial aid and causes increased attrition rates for this already marginalized group, namely those who are Black and Latinx. 
Journal Committed to Social Change on Race and Ethnicity | Volume 6, Issue 2 | 2020

\section{What is the Higher Education Act of 1965?}

The Higher Education Act of 1965 (HEA) was signed into law on November 8, 1965. Its purpose was to strengthen the education resources of our colleges and universities and to create a financial assistance structure for students who wanted to pursue a postsecondary degree, particularly those from disadvantaged populations (Higher Education Act of 1965, 1965). The Act established major federal student aid programs (e.g., Pell Grant, federal work-study programs, unsubsidized loan programs; Congressional Research Service, 2006). In the initial bill, policymakers called for increased opportunities in higher education for lower and middle-income families. The bill increased federal money given to universities, created scholarships, gave lowinterest loans for students, and established a National Teachers Corps. The "financial assistance for students" is covered in Title IV of the HEA. In the 2015-2016 academic year through the Pell Grant alone, the HEA supported 39\% percent of students enrolled in any form of postsecondary education (Dortch, 2018).

As with many laws, the HEA has been updated, reauthorized, and amended in the past 60 years. In 1998 it received a significant overhaul (HEA98). Of particular significance is the added provision in Title IV, Part G, Section 483(r), in which new guidelines were provided by which to suspend a student's eligibility for federal financial aid for "Drug-Related Offenses" (Higher Education Amendments of 1998, 1998, p. H.R. 6-156). Under the provision, conviction for possession of a controlled substance leads to an aid ineligibility period of one year for a first offense, two years for a second offense, and indefinite time for a third offense. Conviction for the sale of a controlled substance leads to an aid ineligibility period of one year for a first offense and indefinite 
Journal Committed to Social Change on Race and Ethnicity | Volume 6, Issue 2 | 2020

time for a second offense. If the conviction is reversed or if a compliant drug rehabilitation program is completed, the provision also allows those affected to become eligible for federal aid again.

As a consequence of this provision in HEA98, a new question was added to the Free Application for Federal Student Aid (FAFSA) form (Skarin, 2010). The question requires applicants to disclose if they have ever been convicted of a drug offense. An affirmative answer requires the applicant to complete an additional form to determine their eligibility for federal financial aid. The FAFSA form is also commonly used to determine an applicant's eligibility for state and institutional financial aid with the same requirements regarding suspension of eligibility on account of drug-related convictions.

In 2006, the group Students for Sensible Drug Policy (SSDP) challenged the HEA98 amendments to revoke federal financial aid from those convicted of drug offenses in federal court, arguing that these amendments discriminately targeted a specific population of individuals and that they acted as an additional judicial sentence to those already convicted in court (SSDP v. Spellings, 2006). This District Court case and its subsequent appeal were both rejected on the basis that the specific population of individuals subject to this policy are not categorized by race, gender, or religion and that the added penalty was not equivalent to additional criminal sentencing (Skarin, 2010). Still, as a result, the provision was scaled back and now applies to those who commit their offense while receiving Title IV federal aid (Skarin, 2010). From 2000-2006, the period from when the policy was enacted to when it was challenged in court, nearly 200,000 students were denied federal financial aid through the specific amendments targeting drug offenders (Skarin, 2010). In recent years since the policy was scaled 
Journal Committed to Social Change on Race and Ethnicity | Volume 6, Issue 2 | 2020

back, the policy has continued to block federal aid for approximately 1,000 students each academic year (Kreighbaum, 2018).

The amendments included in HEA98 specifically target drug offenders above any other criminal offenders. This leads us to our guiding questions for this paper: How has this focus on drug offenders disenfranchised college students and prospective college students with prior drug-related convictions? Second, how does this disenfranchisement affect specific racially minoritized groups? With our analysis framed by critical race theory (CRT) and critical race praxis in education (CRP-Ed), we argue that the policy is problematic in three ways: (a) it disproportionately affects People of Color; (b) it does not reduce recidivism rates; and (c) it extends an already disparate racial caste system within higher education.

\section{Universities as White Property}

Harris (1993) states that being White comes with economic privileges; without fear of being the object of one's domination is "the valorization of whiteness as treasured property in a society structured on racial caste" (p. 1713). Banning students from accessing financial aid is upholding this racial caste system because Black and Latinx people are disproportionately affected by this policy. It is a form of colorblind racism.

Whiteness as property is so embedded that it is rarely noticed (Harris, 1993). It is invisible—no one questions the university for admitting White students in the same way the presence of Black students on college campuses is called into question (Harris, 1993). Whiteness as property operates at colleges and universities with the set of assumptions, privileges, and benefits that accompany the status of being White have 
Journal Committed to Social Change on Race and Ethnicity | Volume 6, Issue 2 | 2020

become a valuable asset that White people sought to protect and that those who passed sought to attain, unlawfully and by fraud if necessary. Harris (1993) examines how White people have come to expect and rely on these benefits, and over time these expectations have been affirmed, legitimized, and protected by the law. Though Black and Latinx people are disproportionately affected by the ban on financial aid, we also understand White people are impacted by the HEA98.

It is important that we understand that law is neither equitable nor explicit in all instances, however, what remains constant is upholding settled expectations of the law based on White privilege (Harris, 1993). Harris argues that American law has always recognized property interest in the frame of White supremacy. We argue that American colleges and universities are White property. To gain access, students with drug felonies must produce unnecessary amounts of documentation that create application and enrollment attrition (Weissman et al., 2010). In a report by Weissman et al. (2010), students were documented as suffering from application fatigue, having to produce paperwork to satisfy the admissions staff, and many of the same issues persist for students during their application for financial aid.

Harris (1993) details the interaction between the construction of race and property and reflects on how rights in property are reliant on, intertwined with, and conflated with race. The question begs then, who has access to higher education? The structure in its early beginnings was built mainly for White male students and built by Black people—many of whom were enslaved (Wilder, 2013). We argue that banning students who were formerly convicted of drug felonies is in line with the hegemonic 
Journal Committed to Social Change on Race and Ethnicity | Volume 6, Issue 2 | 2020

system of White property rights, the HEA98 strategically disenfranchises People of Color in an attempt to preserve hegemony (i.e., Whiteness).

\section{Analytical Framework}

We use CRT and CRP-Ed to center the voices of a systematically oppressed group. While drug offenders comprise a small percentage of students on college campuses due to barriers in access, for many reasons those who do manage to enroll are more at-risk to dropout (Weissman et al., 2010). By utilizing CRT and CRP-Ed as a lens, we will make recommendations for policy that we believe are racially equitable. We use CRT because it centers race and racism and reaches across disciplines, extending its tenets to various areas of research. Below we briefly unpack the tenets of each theory.

\section{Critical Race Theory (CRT)}

Critical race theorists center race and racism in systems of law enforcement, legislation, public/governmental institutions, and research to elucidate how racial inequities are maintained for People of Color in hegemonic environments that ultimately serve Whiteness and White supremacy (Lynn \& Dixson, 2013). Although CRT centers race and racism, CRT scholars recognize that racial identity and racialized oppression intersect with other subordinated identities and forms of oppression that influences lived experiences (Bartlett \& Brayboy, 2005; Brayboy, 2005; Kumasi, 2011; Lynn \& Adams, 2002; Solorzano \& Yosso, 2001). We argue it intersects with People of Color who have been subjected to incarceration for drug offenses.

We acknowledge that there are several iterations of CRT, there is not one prescribed set of tenants. Utilizing Delgado \& Stefancic (2012), we offer five tenets that 
Journal Committed to Social Change on Race and Ethnicity | Volume 6, Issue 2 | 2020

help shape our paper: (a) race is socially constructed and race and racism is central to U.S. society; (b) the theory challenges dominant ideology, such as colorblindness, a post-racial society, and meritocracy; (c) centrality of experiential knowledge is vital as it is a tool to combat hegemonic narratives; (d) racial realism; and, (e) intersectionality.

The Centrality of Race and Racism. Race and racism cannot be overstated in this paper. Race is even present in an all-white town (Roediger, 1999). The creation of racial categories submits how in a racialized society whiteness is positioned as norminalized (Picower, 2009). We assert that race and racism are central when understanding the lived experiences of people who have been convicted of drug crimes.

Challenge of Dominant Ideology. CRT challenges dominant ways of thinking and critiques liberalism (Delgado \& Stefancic, 2012); challenging dominant ideology is central to this paper. CRT also points out how dominant ideology hides racist structures that perpetuate and maintain racial inequities. Dominant ideology enables oppressive structures to be hidden and allows their existence to be normalized (Delgado \& Stefancic, 2012).

Experiential Knowledge of People of Color. In order for People of Color to gain access, equity, and power (and be seen as human) their stories must be centered. Stories have power, CRT encourages a focus on narratives that center the experiential knowledge and voices of marginalized populations (Delgado \& Stefancic, 2012).

Racial Realism. Racial realism asserts that race is a socially constructed idea that has been invented and reinvented over time by people who have power. Because of this, race becomes normalized and shapes everyday encounters of race and racism experienced by People of Color in the United States (Delgado \& Stefancic, 2012). 
Journal Committed to Social Change on Race and Ethnicity | Volume 6, Issue 2 | 2020

Intersectionality. People's racial identities interact with social identities and intersect with other identity-specific experiences to create their unique personal and political lives (Crenshaw, 1991).

\section{Critical Race Praxis in Education}

Borrowing from Yamamoto (1997) and Jayakumar and Adamian (2015), we pair CRT with CRP-Ed to connect the educational experiences of drug offenders within a racial frame. According to Freire (1970), praxis is a practice that is strategic and intentional, it is directed at the structures to be transformed. Praxis is reflection as well as action that is grounded in critical consciousness (Freire, 1970). The idea of critical race praxis is to engage in the literature, grapple with the interlocking forms of racial identity, and the multiple facets of oppression—as we work towards racial justice (Jayakumar \& Adamian, 2015; Yamamoto, 1997).

CRP-Ed is a tool to guide an understanding of justice, equity, and decolonization in the research (Jayakumar \& Adamian, 2015). For each of the four main tenets of CRPEd, we offer a short explanation:

Relational Advocacy Toward Mutual Engagement. This tenet calls for a multilayered approach that challenges the dominant narrative across different spheres of influence (Jayakumar \& Adamian, 2015). In relation to this tenet, Jayakumar and Adamian (2015) discuss the importance for various counter-stories and counteractions that challenge hegemony. They discuss how relational advocacy toward mutual engagement requires working within oppressive policy constraints with a critical consciousness, while at the same time changing policy. 
Journal Committed to Social Change on Race and Ethnicity | Volume 6, Issue 2 | 2020

Redefining Dominant and Hegemonic Systems. Jayakumar and Adamian (2015) describe this tenet as being dedicated to identifying and transforming hegemonic frameworks informed by critical consciousness. Scholars have avowed that race and racism is central to the U.S. legal system and its institutions since their origin. These laws and policies adversely impact the lived experiences and economic realities of People of Color (Delgado \& Stefancic, 2017). Identifying racism allows for resistance across multiple contexts and audiences, including counter-stories within the legalframed research literature (Jayakumar \& Adamian, 2015).

Research as Dialectical Space. Jayakumar and Adamian (2015) acknowledge the racist legacy of research and White methods. White research methods remind us that research is situated within a context where racist policies and practices are perpetuated through White logic. White logic places phenomena, current issues, and practices into an ahistorical context that emerges from preexisting frames with roots in a legacy of racial injustice. In contrast, research as a dialectical space calls us to engage in advocacy scholarship within the hegemonic system as an object of critique toward the production of counteractions (Jayakumar \& Adamian, 2015).

Critical Engagement with Policy. Rooted in the concept of interest convergence (Ladson-Billings \& Tate, 1995), critical engagement toward policy change requires that social change and progress occur when the interests of the dominant group align with the interest of the marginalized group (Jayakumar \& Adamian, 2015). Ultimately, CRP-Ed is useful because it names how People of Color are disproportionately underserved by social institutions including justice and educational systems (Alexander, 2010; Kozol, 2005; Ladson-Billings \& Tate, 1995). 
Journal Committed to Social Change on Race and Ethnicity | Volume 6, Issue 2 | 2020

Ideologies of whiteness and cultural racism would make us believe that People of Color are imprisoned because of their culturally deficient ways of living, thus associating them with criminality (Bonilla-Silva, 2006; Hill, 2017). Research shows this is not true; drug use is the same across disaggregated Black, Latinx, and White populations (National Survey on Drug Use and Health, 2014). Using this framework, we outline how People of Color have been systematically mass incarcerated by policies that specifically target Black and Latinx communities, which in turn has established barriers against access to higher education.

\section{Surveillance and Incarceration of Black and Latinx People}

Alexander (2010) states that "nothing has contributed more to the systematic mass incarceration of People of Color in the United States than the War on Drugs" ( $p$. 18). Drug law infractions have been the main conviction for new prisoners for decades (Drug Policy Alliance, 2016). The Brookings Institution found that there were more than 3 million admissions to prison for drug offenses between 1993 and 2009 in the United States (Rothwell, 2015). Each year during that period, more people were admitted to prison for drug violations than for violent crimes (Rothwell, 2015). During that time, there were more than 30 million arrests citing drug violations (Rothwell, 2015).

It is important to note that a under the Comprehensive Drug Abuse Prevention and Control Act of 1970 (1970), "it is unlawful to manufacture, distribute, or dispense, or possess with intent to manufacture, distribute or dispense a controlled substance; or to create, distribute, or dispense, or possess with intent to distribute or dispense, a counterfeit substance" (p. 1260). These are non-violent offenses, and most are 
Journal Committed to Social Change on Race and Ethnicity | Volume 6, Issue 2 | 2020

classified as felonies. We outline below data that describes the racial representation of people incarcerated for drug-related offenses both presently and in recent decades.

\section{Historical Trends in Incarceration by Race}

In 2018, there were roughly $1,541,000$ people incarcerated in federal or state prisons, with the vast majority (85\%) in state prisons alone (Wagner \& Sawyer, 2018). There are another 750,000 people in other forms of custody including local jails or youth incarceration centers. Of these 2.3 million people, 460,000 (20\%) have a drug offense as their most serious charge (Wagner \& Sawyer, 2018). Of these 460,000 people, the vast majority (85\%) were arrested for drug possession or use, with the remainder for drug sale or manufacturing (Wagner \& Sawyer, 2018). More than 3.7 million additional individuals are on probation, and 840,000 individuals are on parole (Wagner \& Sawyer, 2018). Of these people, Black, Latinx, and American Indian/Alaskan Native populations are substantially over-represented and White populations are substantially underrepresented (Wagner \& Sawyer, 2018).

This disproportionate racial/ethnic representation in incarceration is not a recent anomaly. Snyder (2011) described the trend in drug offenses among different racial groups for the 30 years between 1980 and 2009. Though this data is disaggregated by race and does not indicate representation from Latinx populations, the historic racial disparity is clear in comparison between Black and White populations. Also evident in the data is the effect federal policy has on incarcerated populations. There are substantial increases in the arrest rate corresponding with the passing of the federal Anti-Drug Abuse Acts of 1986 and 1988 and the establishment of the War on Drugs, and as well with the 1994 Crime Bill (Snyder, 2011). All of these trends amplify the 
Journal Committed to Social Change on Race and Ethnicity | Volume 6, Issue 2 | 2020

disproportionate representational fraction of Black populations in comparison with White populations.

An important additional piece of data concerns the disaggregation of actual illicit drug use by race-the disparities described above could just be residual if Black and Latinx populations simply do more drugs than White populations. However, this is unsupported by data. According to the 2014 National Survey on Drug Use and Health, White individuals reported drug use in the year prior (16.1\%) at roughly the same rate as Non-Latinx Black individuals (16.4\%) and Latinx individuals (14.7\%) (National Survey on Drug Use and Health, 2014). Given equitable surveillance and policing, the arrest rates should reflect these values. An equally representative number of the people using drugs from each racial/ethnic population should be arrested, but significantly more Black individuals are arrested than White individuals (Snyder, 2011).

Almost $80 \%$ of people in federal prison and almost $60 \%$ of people in state prison for drug offenses are Black or Latinx (Bureau of Justice Statistics, 2014). Black and Latinx people are disproportionately impacted by surveillance and incarceration policies. Many of the arrests stem from prejudicial and predatory policing of Black and Latinx people (Alexander, 2010; Hill, 2017). Furthermore, it stems from state-sanctioned occupation of these communities via the War on Drugs and the practice of "brokenwindows policing," ${ }^{2}$ which is a practice that emphasizes over-policing of minor infractions in areas perceived to be high-risk for criminogenic behavior-these areas are typically inhabited predominantly by racially minoritized populations (Hill, 2017; United States Department of Justice, 2016). People of Color are disproportionately policed and

\footnotetext{
${ }^{2}$ Broken-windows policing is a theory that argues law enforcement should focus its efforts on low-level crimes to prevent more serious ones (Hill, 2017; United States Department of Justice, 2016).
} 
Journal Committed to Social Change on Race and Ethnicity | Volume 6, Issue 2 | 2020

convicted of drug offenses, hence the amendments in HEA98 focusing explicitly on drug offenders systematically targets People of Color. This refutes the basis on which the federal court dismissed the initial challenge in SSDP v. Spellings (2006), in which it was argued that drug offenders are not a protected group under the United States Constitution (Skarin, 2010).

\section{Deterrent for Drug Use}

Drug use and criminal behaviors are nuanced and complex. The federal aid eligibility ban applies to individuals convicted of a drug offense; however, many of those convicted of a drug offense did not use drugs themselves and have no or minimal prior encounters with the criminal justice system (Bureau of Justice Statistics, 2014; Griffin et al., 2018; Mauer, 2015). More than half (56\%) of the 377,860 drug convictions in 2013 were for intent to sale (Bureau of Justice Statistics, 2014). Some people who sell drugs do so to support their own drug use or addiction, but many do so as a means to survive poverty (Mauer, 2015). A significant fraction of the other $44 \%$ of drug convictions were for the offense of possession with intent to deliver, a charge involving sale of drugs (Bureau of Justice Statistics, 2014). The HEA98 amendments apply to these people convicted of a drug crime who do not use drugs - who are overwhelmingly People of Color-but does not apply to drug users who have been convicted not of drug crimes but of violent crimes like robbery, grand larceny, manslaughter, or murder.

The author of the drug crime provision in HEA98, former Congressman Mark Souder, introduced the amendment as a preemptive deterrent to student drug use on a campus of higher education (Skarin, 2010). The Government Accountability Office (2005) found no evidence that this policy had any deterrent effect on campus drug use. 
Journal Committed to Social Change on Race and Ethnicity | Volume 6, Issue 2 | 2020

It seems evident that the political and social ideology of the time represented by the "War on Drugs" played a more significant role in the formulation of the policy than datadriven recommendations (Lovenheim \& Owens, 2014; Skarin, 2010).

\section{Racist Profiling of Drug Offenders}

There is evidently no empirical data available to describe the effect that the presence of drug offenders has on the overall safety or well-being for the student body on a college campus. However, there are some recent studies that explore the effect of admissions policies that screen applicants according to prior convictions (Custer, 2016; Gregory \& Janosik, 2012). These studies indicate that this admissions screening policy shows it has no effect on campus crime and students' perception of safety (Gregory \& Janosik, 2012). Further, Custer (2013) demonstrated at one four-year public institution that of the 37 students in the study who had been convicted of felonies and were granted admission, zero students violated any student conduct policy. Though more intentional quantitative studies would provide a more definitive conclusion, we claim that the presence of formerly convicted individuals on college campuses, including those convicted of drug crimes, shows no correlation with campus crime rate or students' perceptions of safety.

Through the HEA, the federal government regulates the dispersal of federal financial aid (mainly Pell Grants and subsidized loans) to students in higher education with the FAFSA. After the HEA98, FAFSA applicants were required to state if they had previously been convicted of a felony (Skarin, 2010), even though higher education has been demonstrated as an important method of reducing recidivism in ex-convicts (MacKenzie, 2006). This alone contributes to attrition in those who must disclose their 
Journal Committed to Social Change on Race and Ethnicity | Volume 6, Issue 2 | 2020

conviction in the higher education application process (Weissman et al., 2010). As stated previously, the only two types of felony offenses that explicitly disqualify students from being eligible for federal financial aid are sex offenses and drug offenses. This policy was intended to be a deterrent to students from committing drug crimes on college campuses (Skarin, 2010), yet it has had no discernible effect as such (Government Accountability Office, 2005), and further the inclusion of these populations on campuses has no discernible effect on campus crime rates (Custer, 2013; Custer, 2016; Gregory \& Janosik, 2012). Because racially minoritized populations are disproportionately convicted of felony drug charges (Snyder, 2011), the explicit restriction of federal financial aid for higher education in populations convicted of drug offenses is racially-discriminatory.

\section{Recidivism in Drug Offenders}

In the previous sections we established that Black and Latinx people are disproportionately targeted for and convicted of drug crimes, and hence are disproportionately targeted by the amendments in HEA98 (i.e., the amendments in HEA98 are inherently racist and, by extension, unconstitutional under the Fifth Amendment). We also established that attempts to deter individuals from committing drug crimes by threatening the revocation of federal financial aid have no discernible effect on the occurrence of drug crimes, and that the presence of previously incarcerated individuals has no deleterious effect on a campus environment.

We will now assess the value that higher education can provide to previously convicted individuals, namely the extent to which higher education reduces recidivism in those convicted of drug crimes. If higher education is a mechanism that can benefit 
Journal Committed to Social Change on Race and Ethnicity | Volume 6, Issue 2 | 2020

individuals previously convicted of drug offenses and in turn society, then it must be made accessible to those individuals, and the accessibility of higher education today is contingent on the availability of federal subsidies (Lovenheim \& Owens, 2014).

We start by investigating recidivism policies and programs, which are intended to help reintegrate convicted offenders into society. Recidivism is often used in policy recommendations regarding the effectiveness of the judicial system. A low rate of recidivism among a certain target population implies that some judicial program or policy has been effective in "correcting" the criminal's behavior to that which will not disrupt society at large through illegal acts.

To understand what leads to recidivism in those who have been criminally convicted, we must first identify the intended effect of criminal sentencing: the ideological goal of criminal sentencing is to protect the operation of society at large and to reduce the occurrence of future crime (Mackenzie, 2006). Recidivistic crime reduction is the result of effective cognitive behavioral correction through criminal sentencing (Gendreau et al., 1996; Mackenzie, 2006). These correctible cognitive factors include intrinsic motivations, social behavior, and social achievement (Eaglin, 2017; Gendreau et al., 1996). We will now explore how these cognitive behaviors are addressed through criminal sentencing of those convicted of drug crimes.

\section{Correctional Programs for Drug Offenders}

Mitchell, Wilson, and MacKenzie (2007) conducted a meta-analysis of 66 assessments of the effects of correctional incarceration programs intended to treat drug abuse in order to reduce recidivism among drug offenders. They found that in many cases incarceration-based drug abuse treatment is ineffective, though they did note a 
Journal Committed to Social Change on Race and Ethnicity | Volume 6, Issue 2 | 2020

robust correlation with a reduction in recidivism for those populations sentenced to nonincarceration-based programs (Mitchell et al., 2007, p. 355). In contrast, programs that victimize the participants-military-style boot camps, narcotic maintenance programs, and many more-showed no correlation with a reduction in recidivism (Mitchell et al., 2007).

The most common non-incarceration sentencing program is the drug court system (Logan \& Link, 2019). Since the late 1980s, in an effort to reduce the flooding of prisons with drug offenders, states have promoted the sentencing of these individuals to participate in these treatment-based drug courts (Peters \& Murrin, 2000). In these programs, drug offenders are subject to non-incarceration probationary terms in which the offenders are required to participate in society while undergoing rehabilitative drug treatment (Peters \& Murrin, 2000). In the years following the findings from Mitchell et al. (2007), there is still a consensus that this non-incarceration-based sentencing of drug offenders leads to a reduction in recidivistic tendencies relative to incarcerated or untreated populations (Logan \& Link, 2019; Mitchell et al., 2012).

GED and higher education programs facilitate the most substantial reduction in recidivism among drug offenders among any incarceration-based treatment program, whether formalized through rehabilitation programs or not (Anderson, 1995; Brewster \& Sharp, 2002; Davis, 2019; Gallagher et al., 2018; MacKenzie, 2006). By actively reducing access to federal financial aid for postsecondary education in these populations, the HEA98 is actively oppressing Black and Brown bodies. 
Journal Committed to Social Change on Race and Ethnicity | Volume 6, Issue 2 | 2020

\section{Effects of Limiting Federal Financial Aid to Previously Convicted Drug Offenders}

Lovenheim and Owens (2013) demonstrated an empirical link between the amendments in HEA98 and affected individuals' enrollment in higher education institutions. The authors observed that "the temporary prohibition on federal aid caused a large decline in the fraction of drug offenders who enrolled in college within two years of graduating from high school," (Lovenheim \& Owens, 2013, p. 27). While no qualitative data exists to assess the experiences of these students, Lovenheim \& Owens (2013) presented a compelling statistical argument that directly correlated the likelihood of attending college with drug offenders' eligibility to receive federal financial aid.

As U.S. drug laws continue to change, and many prior convictions may be invalidated as now-legal activities, the FAFSA and the college admissions process will have to reconcile with the legalization of marijuana. What is problematic, moreover, is a significant proportion of these felony drug offenses involve the possession, sale, or consumption of marijuana, the legalization of which is spreading (15 states plus the District of Columbia at present). In the imminent future, federal courts must decide first if the sentences for the outdated laws will be commuted, and then if those with prior convictions under the outdated laws will still be ineligible for federal financial aid for higher education.

In the sections above we have demonstrated the benefits of a college degree by increasing a person's lifetime earning potential exponentially (Carnevale et al, 2015); however, we also demonstrate that the HEA98 is racially discriminatory and shuts out People of Color from the college-going process by not making federal financial aid 
Journal Committed to Social Change on Race and Ethnicity | Volume 6, Issue 2 | 2020

available to people thereby decreasing their chances of being able to enroll and complete college. Understanding the cost associated with a public state university is much lower than the cost of incarcerating people, we urge policymakers to reconsider the HEA98 as allowing formerly incarcerated people to pursue a college degree is proven to reduce prison reentry, this is a much sound investment of tax-payers dollars. In the last section we offer recommendation for future research and policy, and practice.

\section{Recommendations for Future Research and Policy}

Researching formerly incarcerated students in higher education is a growing area of scholarship. We were unable to find existing qualitative data that describes the experiences of those who were subjected to the federal financial aid ineligibility period and went on to receive aid to support their enrollment in higher education; with that, we make four recommendations for future research and policy based on our understanding of the racist HEA98 amendments targeting those convicted of drug crimes. First, it would be beneficial to understand the experiences of students applying to college who have a criminal history in order to understand more specifically where the system can be restructured to boost equitable access, specifically as it relates to federal financial aid. Second, it would be beneficial for researchers to employ critical theoretical frameworks to better understand the nuances of students who have been convicted of drug crimes and denied financial aid. Utilizing frameworks like anti-deficit achievement (Harper, 2010) validation theory (Linares \& Muñoz, 2011; Rendon, 2002) and community cultural wealth $($ Yosso, 2005) can communicate to the public how this population navigates higher education. 
Journal Committed to Social Change on Race and Ethnicity | Volume 6, Issue 2 | 2020

The War on Drugs and the mass incarceration of people is not a coincidence, they both marginalize People of Color-the same goes for those who are blocked from college admissions. This leads us to our third recommendation. Researchers must examine how other laws such as the 1988 Anti-Drug Abuse Act and the 1994 Violent Crime Control and Law Enforcement Act continue to lock out current and formerly incarcerated people from attaining a college degree and how these barriers oppressively impact People of Color. Lastly, college campuses and university systems need to invest funding in campus-based programs that support students who have been convicted of drug crimes and/or incarcerated.

We urge policy makers to craft commonsense legislation that opens doors for individuals who were convicted of drug crimes. We call for local, state, and federal governmental systems to re-invest in public colleges and universities to reduce the need for private investments that create conflicting interests with the missions of the institutions (Mukamal \& Silbert, 2018). An educated citizenry correlates with fewer instances of criminal behavior (Weissman et al., 2010). With no evidence showing that limiting access to higher education makes campuses safer, we also add that policy makers should ban the box (Weissman et al., 2010). The need to identify the criminal past of applicants is a perception that is founded in racial and class bias. Upholding this policy without amendment has major financial implications. A year-long Pell Grant award for an individual is substantially less expensive than year-long imprisonment (Weissman et al., 2010). HEA98 continues to disenfranchise People of Color, who are disproportionately represented in our nation's prisons. The U.S. legal system is welldocumented as a racist institution that specifically targets Black and Brown people. For 
Journal Committed to Social Change on Race and Ethnicity | Volume 6, Issue 2 | 2020

progress towards social equity for oppressed racial populations, this institution must be deconstructed to eliminate explicit bias and bias by proxy. 
Journal Committed to Social Change on Race and Ethnicity | Volume 6, Issue 2 | 2020

\section{References}

Alexander, M. (2010). The new Jim Crow: Mass incarceration in the age of colorblindness. New Press.

Anderson, S. V. (1995). Evaluation of the impact of correctional education programs on recidivism. Columbus, $\mathrm{OH}$ : Ohio Department of Rehabilitation and Correction. http://www.ncjrs.gov/

Bartlett, L., \& Brayboy, B. M. J. (2005). Race and schooling: Theories and ethnographies. The Urban Review, 37(5), 361-374. DOI: 10.1007/s11256-0050021-3

Bonilla-Silva, E. (2006). Racism without racists: Color-blind racism and the persistence of racial inequality in the United States. Rowman \& Littlefield Publishers.

Brayboy, B. M. J. (2005). Toward a tribal critical race theory in education. The Urban Review, 37(5), 425-446. DOI: 10.1007/s11256-005-0018-y

Brewster, D. R., \& Sharp, S. F. (2002). Educational programs and recidivism in Oklahoma: Another look. The Prison Journal, 82(3), 314-334. DOI: $10.1177 / 003288550208200302$

Bureau of Justice Statistics. (2014). Federal justice statistics program: Prisoners in 2014. http://www.bjs.gov/fjsrc

Burnsed, B. (2011, Aug. 5). How higher education affects lifetime salary. US News \& World Report. https://www.usnews.com/education/

Carnevale, A. P., Smith, N., Melton, M., \& Price, E. (2015). Learning While Earning: The New Normal. Georgetown University Center on Education and the Workforce. https://1gyhoq479ufd3yna29x7ubjn-wpengine.netdna-ssl.com/wpcontent/uploads/Working-Learners-Report.pdf

Chan, R. Y. (2016). Understanding the purpose of higher education: An analysis of the economic and social benefits for completing a college degree. Journal of Education Policy, Planning and Administration, 6(5), 1-40.

College Board. (2019). Trends in college pricing 2019 (Trends in Higher Education Series). College Board. https://research.collegeboard.org/pdf/trends-collegepricing-2019-full-report.pdf

Comprehensive Drug Abuse Prevention and Control Act of 1970, Pub. L. No. 91-513, § 401, 84 Stat. 1260 (1970). https://www.govinfo.gov/content/pkg/STATUTE84/pdf/STATUTE-84-Pg1236.pdf

Congressional Research Service. (2006). Higher Education Act reauthorization: A comparison of current law and major proposals. Domestic Social Policy Division, Congressional Research Service.

Crenshaw, K. (1991). Mapping the margins: Intersectionality, identity politics and violence against women in color. Stanford Law Review, 43(6), 1241-1299.

Custer, B. (2013). College admissions policies for students with felony convictions: Why they are not working at one institution. College \& University, 88(4), 28-36.

Custer, B. (2016). College admission policies for ex-offender students: A literature review. Journal of Correctional Education (1974-), 67(2), 35-43.

Davis, L. M. (2019). Higher education programs in prison: What we know now and what we should focus on going forward. Rand Corporation. 1-16. DOI: 10.7249/PE342 
Journal Committed to Social Change on Race and Ethnicity | Volume 6, Issue 2 | 2020

Delgado, R., \& Stefancic, J. (2017). Critical race theory: An introduction. NYU Press.

Drug Policy Alliance. (2016). The drug war, mass incarceration and race. https://www.drugpolicy.org/

Dortch, C. (2018). Federal Pell Grant Program of the Higher Education Act: Primer. CRS Report R45418, Version 2. Updated. Congressional Research Service.

Eaglin, J. M. (2017). Constructing recidivism risk. Emory Law Journal, 67(1), 59-122.

Freire, P. (1970). Pedagogy of the oppressed (M. Bergman Ramos, trans.). Continuum.

Gallagher, J. R., Wahler, E. A., Lefebvre, E., Paiano, T., Carlton, J., \& Woodward Miller, J. (2018). Improving graduation rates in drug court through employment and schooling opportunities and medication-assisted treatment (MAT). Journal of Social Service Research, 44(3), 343-349. DOI: 10.1080/01488376.2018.1472173

Gendreau, P., Little, T., \& Goggin, C. (1996). A meta-analysis of the predictors of adult offender recidivism: What works! Criminology, 34(4), 575-608. DOI: 10.1111/j.1745-9125.1996.tb01220.x

Government Accountability Office. (2005). Drug offenders: Various factors that may limit the impacts of federal laws that provide for denial of selected benefits. United States Government Accountability Office. https://www.gao.gov/assets/250/247940.pdf

Gregory, D. E., \& Janosik, S. M. (2012). Research on the Clery Act and crime reporting: Its impact on the literature and administrative practice in higher education. In B. S. Fisher \& J. J. Sloan (Eds.), Campus Crime: Legal, Social, and Policy Perspectives. Thomas Books.

Griffin, O. H., Griffin, V. W., Copes, H., \& Dantzler, J. A. (2018). Today was not a good day: Offender accounts of the incidents that led to their admission to drug court. Criminal Justice Studies, 31(4), 388-401. DOI: 10.1080/1478601X.2018.1516215

Gross, J. P.K, Berry, M., \& Reynolds, P. (2015). The Differential Effects of Financial Aid on Degree Completion by Gender. Strategic Enrollment Management Quarterly, 3(1), 41-61. DOI: 10.1002/sem3.20060

Gross, J. P.K., Torres, V., \& Zerquera, D. (2012). Financial aid and attainment among students in a state with changing demographics. Research in Higher Education. 54(4), 383-406 DOI: 10.1007/s11162-012-9276-1

Harper, S. R. (2010). An anti-deficit achievement framework for research on students of color in STEM. New Directions for Institutional Research, 2010(148), 63-74. DOI: 10.1002/ir.362

Harris, C. I. (1993). Whiteness as property. Harvard Law Review. 106(8),1707-1791. DOI: $10.2307 / 1341787$

Henrichson, C., \& Delaney, R. (2012). The price of prisons: What incarceration costs taxpayers. Federal Sentencing Reporter, 25(1), 68-80. DOI: 10.1525/fsr.2012.25.1.68.

Higher Education Act of 1965, Pub. L. No. 89-329, 79 Stat. 1219-1270. (1965). https://www.govinfo.gov/content/pkg/STATUTE-79/pdf/STATUTE-79Pg1219.pdf\#page $=37$

Higher Education Amendments of 1998, H.R. 6, 105th Cong. (1998). https://www2.ed.gov/policy/highered/leg/hea98/index.html

Hill, M. L. (2017). Nobody: Casualties of America's war on the vulnerable, from Ferguson to Flint and beyond. Simon and Schuster. 
Journal Committed to Social Change on Race and Ethnicity | Volume 6, Issue 2 | 2020

Jayakumar, U. M., \& Adamian, A. S. (2015). Toward a critical race praxis for educational research: Lessons from affirmative action and social science advocacy. Journal Committed to Social Change on Race and Ethnicity, 1(1), 2258. DOI: 10.15763/issn.2642-2387.2015.1.1.21-58

Kozol, J. (2005). The shame of the nation: The restoration of apartheid schooling in America. Broadway Books.

Kreighbaum, A. (2018, March 7). New push to drop drug offenses as barrier to student aid. Inside Higher Ed. https://www.insidehighered.com/.

Kumasi, K. D. (2011). Critical race theory and education: Mapping a legacy of activism and scholarship. In B. A. Levinson, J. P. K. Gross, C. Hanks, J. Heimer Dadds, K. Kumasi, \& J. Link (Eds.), Beyond critique: Exploring critical social theories and education (pp. 208-231). Routledge.

Ladson-Billings, G., \& Tate, W. F. (1995). Toward a critical race theory of education. American Educational Research Journal, 32(3), 465-491. DOI: 10.2307/1163320

Linares, L. I. R., \& Muñoz, S. M. (2011). Revisiting validation theory: Theoretical foundations, applications, and extensions. Enrollment Management Journal, 2(1), 12-33.

Logan, M. W., \& Link, N. W. (2019). Taking stock of drug courts: Do they work? Victims \& Offenders, 14(3), 283-298. DOI: 10.1080/15564886.2019.1595249

Lovenheim, M. F. \& Owens, E. G. (2014). Does federal financial aid affect college enrollment? Evidence from drug offenders and the Higher Education Act of 1998. Journal of Urban Economics, 81(C), 1-13. DOI: 10.1016/j.jue.2014.01.005

Lynn, M., \& Adams, M. (2002). Introductory overview to the special issue critical race theory and education: Recent developments in the field. Equity \& Excellence in Education, 35(2), 87-92. DOI: 10.1080/713845285

Lynn, M., \& Dixson, A. D. (Eds.). (2013). Handbook of critical race theory in education. Routledge.

MacKenzie, D. L. (2006). What works in corrections: Reducing the criminal activities of offenders and delinquents. Cambridge University Press.

Mauer, M. (2015). A lifetime of punishment: The impact of the felony drug ban on welfare benefits. The Sentencing Project. http://www.sentencingproject.org

Mitchell, O., Wilson, D. B., \& MacKenzie, D. L. (2007). Does incarceration-based drug treatment reduce recidivism? A meta-analytic synthesis of the research. Journal of Experimental Criminology, 3(4), 353-375. DOI: 10.1007/s11292-007-9040-2

Mitchell, O., Wilson, D. B., Eggers, A., \& MacKenzie, D. L. (2012). Assessing the effectiveness of drug courts on recidivism: A meta-analytic review of traditional and non-traditional drug courts. Journal of Criminal Justice, 40(1), 60-71. DOI: 10.1016/j.jcrimjus.2011.11.009

Mukamal, D., \& Silbert, R. (2018). Don't Stop Now: California leads the nation in using public higher education to address mass incarceration. Will we continue? Stanford Law School, Stanford Criminal Justice Center. https://law.stanford.edu/publications/

National Survey on Drug Use and Health. (2014). Results from the 2014 National Survey on Drug Use and Health: Detailed tables. https://www.samhsa.gov/ 
Journal Committed to Social Change on Race and Ethnicity | Volume 6, Issue 2 | 2020

Olson, D. E., Stalans, L. J., \& Escobar, G. (2016). Comparing male and female prison releasees across risk factors and postprison recidivism. Women \& Criminal Justice, 26(2), 122-144. DOI: 10.1080/08974454.2015.1083930

Peters, R. H., \& Murrin, M. R. (2000). Effectiveness of treatment-based drug courts in reducing criminal recidivism. Criminal Justice and Behavior, 27(1), 72-96. DOI: $10.1177 / 0093854800027001005$

Picower, B. (2009). The unexamined whiteness of teaching: How white teachers maintain and enact dominant racial ideologies. Race Ethnicity and Education, 12(2), 197-215. DOI: 10.1080/13613320902995475

Rendón, L. I. (2002). Community college Puente: A validating model of education. Educational Policy, 16(4), 642-667. DOI: 10.1177/0895904802016004010

Roediger, D. R. (1999). The wages of whiteness: Race and the making of the American working class. Verso.

Rothwell, J. (2015), Drug offenders in American prisons: The critical distinction between stock and flow. Brookings Institution blog. http://www.brookings.edu/

Salinas Jr, C., \& Lozano, A. (2019). Mapping and recontextualizing the evolution of the term Latinx: An environmental scanning in higher education. Journal of Latinos and Education, 18(4), 302-315. DOI: 10.1080/15348431.2017.1390464

Skarin, E.A. (2010). SSDP v. Spellings: Judiciary acquiescence of law with racially discriminatory effects. Journal of Gender, Race \& Justice, 14(1), 301-326.

Snyder, H. N. (2011). Arrests in the United States, 1980-2009. Bureau of Justice Statistics. http://www.bjs.gov/

Solorzano, D. G., \& Yosso, T. J. (2001). Critical race and LatCrit theory and method: Counter-storytelling. International Journal of Qualitative Studies in Education, 14(4), 471-495. DOI: 10.1080/09518390110063365

Students for Sensible Drug Policy v. Spellings, 460 F. Supp. 2d 1093 (D.S.D. 2006).

United States Department of Justice. (2016). Investigation of the Baltimore City Police Department. https://www.justice.gov/crt.

Wagner, P., \& Sawyer, W. (2018). Mass incarceration: The whole pie 2018. Prison Policy Initiative. https://www.prisonpolicy.org/

Weissman, M., Rosenthal, A., Warth, P., Wolf, E., \& Messina-Yauchzy, M. (2010). The use of criminal history records in college admissions reconsidered. The Center for Community Alternatives. http://www.communityalternatives.org.

Wilder, C. S. (2014). Ebony and ivy: Race, slavery, and the troubled history of America's universities. Bloomsbury Press.

Yamamoto, E. K. (1997). Critical race praxis: Race theory and political lawyering practice in post-civil rights America. Michigan Law Review, 95(4), 821-900. DOI: $10.2307 / 1290048$

Yosso, T. J. (2005). Whose culture has capital? A critical race theory discussion of community cultural wealth. Race ethnicity and education, 8(1), 69-91. DOI: $10.1080 / 1361332052000341006$ 